\title{
Swimming with the Tide-A living Theory Approach to Religious Education
}

\author{
Kari Flornes \\ Bergen University College, Norway
}

\begin{abstract}
The theoretical framework of this paper is based on the living theory of practice developed by Jack Whitehead. Whitehead holds the view that theory is an outcome of practice and that the practitioner, being an expert of her or his practice, is capable of improving practice by systematically acting, observing, reflecting, evaluating and theorizing about practice. In this research spiral activity, the main question is: How do I improve what I am doing? By introducing teacher students to action research and living theories in the process of becoming religious education teachers, they are empowered to investigate and to analyse their practice right from the beginning of their life as practitioners. In this process their personal values and the values emerging from the variety of RE themes will inform their critical reflection about to what extent they are able to mirror these values in their actions in the classroom, particularly in their interactions with pupils. Theses purposeful activities will advance their knowledge about what they are doing and inform their evaluation of the quality of teaching and learning constructed in their practices. Teachers or practitioner - researchers who are able to systematically observe their practice, are in the position of minimizing the gap between values and actions and to give scholarly and informed explanations for what they are doing in the RE classroom.
\end{abstract}

Keywords: swimming with the tide, living theory of practice, religious education

\section{Introduction}

During the last study year, his main work in teacher education has been in the field of religious education with a group of student teachers in their second year of training to become an RE teacher. In the autumn term of the study-year of 2012-2013, one week was dedicated to transversal knowledge or soft skills like Human Rights Education, Citizenship and how to grow personally and professionally as a teacher. Didactical and pedagogical questions were focused both from a transversal, interdisciplinary perspective and from a specific subject perspective. The RE students created a fictional journey through the five world religions, presented on posters having the title: an educational journey through the five world religions; Judaism, Christianity, Islam, Buddhism and Hinduism. For a plenary session that ended the program of the week, a group of these RE students chose to create a dance, with the title: The Five World Religions Presented through a Dance Lasting for Four and a Half Minutes.

They have been able to watch this performance live twice and each time they have been deeply moved, both by the beautiful movements these students are able to create and how much they are inspired and

Kari Flornes, associate professor, Department of teacher education/Religious Education, Bergen University College. Correspondence concerning this article should be addressed to Bergen University College. E-mail: Kari. Flornes@hib.no. 
concentrated while listening to the music that has been composed in several religious traditions.

\section{Swimming against or with the Tide}

The experience reported above, made him think about the first action research $\mathrm{PhD}$ thesis he was able to retrieve and read in the School of Education Library at the University of Birmingham, UK. The title of that thesis was: Swimming against the tide, and reports in addition to the scientific research results, the struggle this $\mathrm{PhD}$ candidate had to face in order to write a thesis as an action research report. It was like swimming against the tide because this kind of report focusing on one researcher's personal and professional experience was quite new back in 2005 at this university. The main obstacle was to be allowed to write a PhD thesis from a first person perspective.

Today action research and first person reports are fully accepted and so have the inclusion of video and multimedia reports as claim to validity and credibility of this kind of research. Jack Whitehead(2006)has strongly contributed to this development.

Their students created a beautiful, harmonious dance where religious music inspired them to present a piece of art that conveyed the beauty of religions without using words, but movements and music. The motivation for creating this dance came from a drama course that all students have to take as a compulsory training in their first year of teacher education. Their inspiration for writing this paper comes from watching this dance, being performed by their students. As an action researcher they fully recognize that in many situations, actions may speak louder than words.

\section{The Power of Multimedia and Visual Reports}

As a teacher educator of the student teachers who performed this dance, he was pleased to see how professional they were as they presented themselves visually and kinesthetically in a very competent way.

He was impressed and even surprised to see how well they did this as they had no information or previous experience that could reveal these talents among his students. The fact that the dance was video-taped gave them an opportunity to engage in a conversation about the experience. For student teachers who have very little experience from the classroom, professional conversations about practice is a challenge. Often they are not familiar with the concepts and words to use for their practice descriptions. Whitehead sees multimedia as a powerful tool to use in educational conversations as "it captures the nature of reality in a way that verbal reports cannot” (Whitehead \& McNiff, 2006, p. 75).

They would argue that multimedia as the object for an educational discussion about practice experiences with students offers a possibility to find words for describing what they feel about what they are doing, their reflections and ideas, what is good, what can be improved and so on. In this way student teachers and teacher educators can engage in a professional conversion about practice experiences and develop their knowledge and language. From an action research perspective, Whitehead(2006) underlines the necessity for an educational practitioner to ask the question: How do I improve what I am doing? As a teacher educator, he feels that there is also a need to ask the question: What do I do when I am good? In order to support both the professional and personal development of future teachers, both perspectives have to be focused and discussed.

In a challenging video about teachers' feedback, an American teacher explains and shows how she works and how she records her lessons in order to analyse what goes on the classroom and how she can improve her practice. 


\section{Religion as Movement}

A recent book about religious education in Norway has the title; Religion as movement (Religion som bevegelse) (Afdal, 2013). The author raises a number of questions connected to learning and the learning of religion. What is learning? How does learning take place? How does learning of religion take place? Does this learning in the present world not only change persons but also religions themselves? These questions are a constant focus of attention for a teacher educator in RE and in their context the following question emerged:

What kind of learning did their students' dance-performance offer into a community of learning in teacher education?

Starting from his own perspective as a teacher educator in RE, he saw the dance as a new way of presenting the five world religions, an inclusive, innovative, esthetical and artistic approach.

They realized that this experience gave their students an opportunity to reveal some of their talents and competences that would never have been materialized in ordinary academic teaching and learning activities. In their reflection about this fact, they clearly saw new perspectives of learning and how learning can take place in a variety of forms. The technological possibilities and the challenge of media and information literacy give them new ways of work, a multitude of teaching and learning activities to explore and create.

How can teacher educators work in order to develop new competences? (Pestalozzi, 2011)Teacher educators have to explore and develop new ways of teaching and learning in order to educate teachers who are media and information literate and are familiar with new learning approaches achieved during their studies and training as future teachers. Every year they experience in teacher education, that many of the newly arrived students are more media and information literate than the teachers in the college. In the years to come, teacher educators have to update their media and information literacy and be able to create suitable frameworks in which students' media and information literacy, their creativity and ability to cooperate are challenged and promoted. For this purpose there is a need for new communities of learning where all members, students and teachers participate in the process as learners in cooperative and creative ways.

\section{Religious Education and Living Theories}

In their reflection about the performance of their students, they came to the conclusion that the success of the dance was linked to the fact that the students were given an opportunity to compose the dance on their own by using their ability to be creative and to cooperate in autonomous ways. Three key words were highlighted in their mind, namely: creativity, cooperation and autonomy.

Even if the drama teacher had given the students some good advice and acted as their mentor and motivator in the creation phase of the dance, the students felt that they were the creators of the dance. They were responsible for the planning, composition of the movements and the music and the distribution of the various roles of the performance. The first performance was given in the autumn term and the last one in the spring term, each event demanding hours of rehearsal before presentations. As future RE teachers they share a common knowledge base and interest in religions and worldviews. Their professional identity as RE teachers was the key impetus to create the dance which is linked to their knowledge of the five world religions: Judaism, Christianity, Islam, Hinduism and Buddhism.

The knowledge of these religions was the guideline for the choice of music. In the group as a whole there was a common interest in religious music and they all shared some experiences in dance and physical activities. 
They did not, however, inhibit any previous experience in composing and performing a dance for a pedagogical purpose for a mixed audience of students and teachers.

The main learning goal was to present key elements from these five religions through the music and the movements that could refer to the religions themselves in forms of music, significant movements and allusions to narratives and persons that could be recognized by the audience.

According to Whitehead (2006), all individuals are born with the capacity to make their own original contribution and engage critically with others. He sees their ontological values as deeply spiritual connections between themselves and others. These values are embodied and made external and explicit through their practices and theories (Whitehead \& McNiff, 2006, p. 86). From this ontological perspective, Whitehead develops his living theories of practice.

\section{Living Theories and Teachers' Practice - Oriented Learning}

One of the main questions in the education of teachers is how they connect theory and practice. Students can read and learn much about various pedagogical approaches like drama, dance and physical activities, but it is in the practice of these activities as they unfold that their knowledge and skills come into being. The experience of doing this, the practice of it affords the opportunity to observe what they are doing and start reflecting on it and make critical judgments about it. For people who work in education, the theories that they develop will be their living educational theories (Whitehead \& McNiff, 2006). These theories will contain the descriptions and explanations educationalists offer for their practices. Often they discover that they present themselves as living contradictions because they experience that the values that they hold are denied in their practices.

One of the students in the dancing group came to such a conclusion after having worked with the values and competences of EDC/HRE (Education for Democracy and Citizenship and Human Rights Education) using the document: How all teachers can support citizenship and human rights education: A framework for the development of competences (2009) from the Council of Europe. In this document there is a clear description of what a teacher who inhibits specific competences in the areas of EDC/HRE is able to demonstrate in the classroom with her/his pupils. The student she is referring believes in democracy and is interested in democratic styles of teaching and interactions with pupils in the classroom. The demonstration of democratic governance in the classroom and in the practice team with her mates was a prime concern for this student. However, after having studied the EDC/HRE competences and how these competences are to be demonstrated by teachers, she came to the conclusion that she was denying the values that she actually holds. She clearly saw that instead of being democratic, she had shown a dominant and authoritarian attitude in the interactions in the team. As this information had been spread to other classmates, there was a reluctant willingness to accept having to cooperate with this person during the new study year.

Accordingly she spent some time reflecting upon whom she could cooperate with and how a new team including this person could be composed.

By composing a team of three, this person in question and two other very competent, strong and clever students, there was a chance that the work would be shared in a good and democratic way. Being eager to find out how these students were getting on, they went to their practice school one of the first days of their time of visiting schools. They were very happy to find a well-functioning team of students who were enthusiastic about their work as a whole and about the work in the team with their mentor and most importantly, they were very 
happy about working with the pupils, a class of 24, 9-10 years old children.

The student, who had been too dominant in the previous practice group, told them, her mates and them, that she had completely changed her attitude this year as she said that,

I realized after having studied the competences in the Council of Europe manual and how these competences are demonstrated in practice that my attitude was too dominant last year, now I try to be more attentive to my mates and listen to their ideas and cooperate with them in a more democratic way.

In her doctoral thesis from 2011, Sigrid Grøtterud shows the importance of democracy in action research. In order to develop a successful participatory action research model, a deep understanding of democratic interactions and governance has to be shared in the research group. There are many ways of achieving this insight. Her student read a text that inspired a critical reflection about personal practice and this reflection led to a change of behavior. In Grøtterud's thesis, the act of writing reflexive texts and discussing participants' experiences, using "love" and "critique" as dominant perspectives, were useful instruments in the change process (Grøtterud, 2011, p. 335-336).

By critically researching their own practices as teacher educators, not only new insight and understanding of what they are doing are revealed, but they are empowered to improve what they are doing, taking informed and effective measures to answer the crucial question: How do I improve my practice? In his own action research project, he started to research his own practice in order to change and improve both himself and his practice. In the Norwegian context this action research model has been taken further by Dag Husebø in his doctoral thesis from 2013.

\section{Conclusion}

The experience reported above was for her as a tutor and teacher educator in RE, a very pleasant experience, indeed. Instead of telling the student what to do and presenting her own views, the change of attitude was promoted by the theories the student had studied and connected to her own experience.

The personal reflection and the critical self-evaluation process that followed, had made her come to the conclusion that she had to improve her practice by changing her attitudes, behavior and actions. According to Harris and Lázár (2011), all models of teacher education are underpinned by the need to provide challenge, experience and reflection. There are reasons to believe that this student had been offered these provisions as she changed from an authoritarian to a democratic participant in a practice team. In addition to the challenges connected to working in a school, there was the tremendous challenge of participating in the dance group and perform this dance for a big audience of students and teachers. According to Atkinson et al., (1993), learning may be defined as a relatively permanent change in behavior that results from practice.

The aurthor considers that the change of student's behavior demonstrates that real learning had taken place. The learning of students is the core focus of his professional work as a teacher educator and as a practitioner researcher, and the research is informed by the living theories of education, developed by Jack Whitehead. He (2006) argues that the living educational theories of professional educators and other practitioner-researchers usually explain their educational influences in the learning of their students and can also explain their educational influences in the learning of social formations. (Whitehead,2006)

By engaging in a creative dance performance inspired by religions, a group of students had to make use of their minds, bodies and spirits in their quest to reach perfection. Each of them did the best of their abilities to create a good performance based on trust and cooperation. For future RE-teachers such experiences, the feeling 
of "swimming with the tide" is important for keeping a strong motivation and enthusiasm for this subject which in Norway's school system is highly debated and influenced by changing political opinions.

Accordingly, in their future career, these RE-teachers will experience that they sometimes will have to "swim against the tide", but the success of their performance while "swimming with the tide" will hopefully both inspire the creation of innovative new pedagogical tools in this important and challenging subject and afford a more solid professional platform to act from.

\section{References}

Afdal, G. (2013) Religion som bevegelse. Oslo: Universitetsforlaget.

Flornes, K. (2007) An action research approach to initial teacher education in Norway. (PhD thesis), Birmingham: The University of Birmingham, UK.

Grøtterud, S. (2011) .Utvikling av veiledningsmøter i praktisk-pedagogisk utdanning. Aksjonsforskning i larerutdannerens praksi Developing Guiding Encounters in Practical and Didactic Education Action Research in Teacher Educators' Practice. (PhD thesis). UMB: Norwegian University of Life Sciences.

Harris, R., \& Lázár, I. (2011). Ways to bring about change in Teacher education for change (pp.105-113). Strasbourg: Council of Europe.

Husebø, D. (2013). Fagdidaktisk utprøving av en fortolkende kulturbevisst tilncerming til Religion, livssyn og etikkundervisning. (PhD-thesis) University of Stavanger.

Learning and living democracy (2009). How all teachers can support citizenship and human rights education: a framework for the development of competences? Strasbourg: Council of Europe Publishing.

Pestalozzi series No.1 (2011). Teacher education for change . Strasbourg: Council of Europe.

Whitehead, J., \& McNiff, J. (2006). Action Research Living Theory. London: Sage Publications. 